\title{
"Diversification of export territories of family businesses as a tool of their further development"
}

Naděžda Petrů iD https://orcid.org/0000-0002-9927-3337

AUTHORS

Andrea Tomášková iD https://orcid.org/0000-0003-1547-2759

R https://publons.com/researcher/3139713/andrea-tomaskova/

Monika Krošláková (D https://orcid.org/0000-0003-0518-9538

Naděžda Petrů, Andrea Tomášková and Monika Krošláková (2019).

ARTICLE INFO

Diversification of export territories of family businesses as a tool of their further development. Problems and Perspectives in Management, 17(3), 306-322. doi:10.21511/ppm.17(3).2019.25

DOI http://dx.doi.org/10.21511/ppm.17(3).2019.25

RELEASED ON Monday, 02 September 2019

RECEIVED ON

Saturday, 06 April 2019

ACCEPTED ON

Tuesday, 28 May 2019

(cc) EY

LICENSE This work is licensed under a Creative Commons Attribution 4.0 International License

JOURNAL Problems and Perspectives in Management"

ISSN PRINT 1727-7051

ISSN ONLINE $1810-5467$

PUBLISHER

LLC "Consulting Publishing Company "Business Perspectives"

FOUNDER

LLC "Consulting Publishing Company "Business Perspectives"

NUMBER OF REFERENCES

56
NUMBER OF FIGURES

0

\section{ニニะ}

NUMBER OF TABLES

7

(C) The author(s) 2023. This publication is an open access article. 


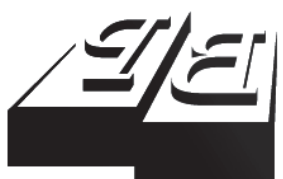

BUSINESS PERSPECTIVES

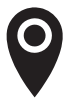

LLC "CPC "Business Perspectives" Hryhorii Skovoroda lane, 10, Sumy, 40022, Ukraine

www.businessperspectives.org

Received on: $6^{\text {th }}$ of April, 2019 Accepted on: $28^{\text {th }}$ of May, 2019

(C) Naděžda Petrů, Andrea

Tomášková, Monika Krošláková, 2019

Naděžda Petrů, Ing., Ph.D.

Department of Business

Management, University of Finance and Administration, Czech Republic.

Andrea Tomášková, Ing., Department of Business Management, University of Finance and Administration, Czech Republic.

Monika Krošláková, Ing., Ph.D. Department of Services and Tourism, University of Economics in Bratislava, Slovakia.

\section{(ㄷ)(ㄱ)}

This is an Open Access article, distributed under the terms of the Creative Commons Attribution 4.0 International license, which permits unrestricted re-use, distribution, and reproduction in any medium, provided the original work is properly cited.
Naděžda Petrů (Czech Republic), Andrea Tomášková (Czech Republic),

Monika Krošláková (Slovakia)

\section{DIVERSIFICATION OF EXPORT TERRITORIES OF FAMILY BUSINESSES AS A TOOL OF THEIR FURTHER DEVELOPMENT}

\begin{abstract}
Family business is the largest global source of jobs in the private sector, whose multigenerational nature strengthens the stability of individual economies. A competitive small and medium-sized enterprise (SME) sector into which family businesses are classified is an essential prerequisite for the full-fledged integration of any economy into the global economic space. For the Czech economy, the importance of foreign trade is increasing, and is dependent on the capabilities of companies to expand to foreign markets. The goal of this article is to identify involvement of the generation of successors to export activities of family business, focusing on diversifying export territories in relation to structure of the industry A secondary goal is to discuss the demand mechanisms for SMEs/family business oriented toward export. The scientific hypotheses defined are focused on demonstrating a dependency between the diversification of export territories, the involvement of the generation of successors in the management of the company and structure of industry. Authors have demonstrated that family businesses managed by the first generation of founders export primarily to the territories of Slovakia, Germany, and the EU. Companies where the next generation contributes to management diversify territorial risk and also export outside the EU countries. A significant correlation was demonstrated between automotive industry and Germany, Slovakia and country outside the EU and mechanical engineering and country outside the EU. The uniqueness of this article lies in the topicality of the real transition of Czech family businesses to the next generation, which carries out foreign trade to promote the further development and sustainability of the family business for future generations.
\end{abstract}

\section{Keywords}

business, export, generations, internationalization, support of export, diversification of export territory, Czech Republic, descriptive statistics, correlation

\section{JEL Classification F40, L60, M20}

\section{INTRODUCTION}

Measures that support the internationalization of small and medium-sized enterprises and their business activities in foreign markets are part of the economic philosophy of most developed countries, particularly those where export contributes in a significant way to generating GDP. Such countries include the Czech Republic, where the ratio of export to GDP hovers around 80\% (MPO, 2018). In recent years, the largest volume of Czech import and export has traditionally taken place within the countries of the European Union, where the position of strongest business partner has been retained by Germany - the most important sales destination for Czech businesses from a territorial perspective. In terms of industries, the majority has consisted of import and export within the automotive industry, in which small and medium-sized companies partner as part of custom manufacturing or subcontracting. And yet this market has its limitations and risks (Tamas, 2018). Diversification of business risks in multiple markets has therefore become a pressing issue. 
Small and medium-sized enterprises are an integral part of every economy (Draskovic, Popov, \& Peleckis, 2017; Belás et al., 2015; Delibasic, 2016; Neagu, 2016; Krošláková et al., 2015; Kubičková et al., 2015; Benešová et al., 2018, 2016; Berlemann \& Jahn, 2015; Chong et al., 2019). These enterprises are more flexible when it comes to adapting to the market changes; they constantly produce and innovate in order to survive in the strong competition battle. They play a significant role in total employment, they fulfill an important task in the course of generation of potential jobs, and they directly contribute to the unemployment reduction (Krošláková et al., 2015). The European Economic and Social Committee (EESC) acknowledges the exceptional value of family businesses which it associates with the Small Business Act initiative. The Committee appeals to the fact that family businesses represent a substantial number of SMEs. Family businesses are the engine of a nation's economy (Sultan, Waal, \& Goedegebuure, 2017; Mareš \& Petrů, 2018; Břečková, 2016). They concentrate economic power, then transfer it to the next generation with the charge to develop it further (Means, 2016). They contribute to solving the economic and social problems of the state (Prasetyo, 2016) and contribute to solving social problems in regional development as well (Žižka, 2013). They have capability and potential to increase the competitiveness of the Czech economy on global markets (Petlina \& Koráb, 2015). Family businesses demonstrate a high level of immunity to economic cycles (Tomášková \& Havlíček, 2018), are less affected by economic crises, and adapt more rapidly to changing market conditions (Szymanska, 2015).

The issues surrounding the entry of family businesses to foreign markets is not a new one on foreign markets in countries where family businesses have a long established tradition. It has been thoroughly analyzed historically and currently by a number of researchers focusing on the influence of the generation newly entering the management of family businesses on the change of their strategic management (Andersen, 1993; Sanders \& Carpenter, 1998; Bell, McNaughton, \& Young, 2001; Meneses, Coutinho, \& Pinho, 2014). Over the long term, the individual generations create a positive brand image, transfer knowledge and know-how, verify the quality of products on offer, diversify export territory, and ensure the growth of the family business (Abel \& Seamus, 2017). The incoming generation then seeks new markets and opportunities for the long-term and sustainable growth of the family business. It eliminates risks associated with entry to foreign markets by diversifying selected territories, products, pricing, communications, etc.

The reason this topic was chosen is its pertinence. The originality and excellence of this article consists of the fact that the recent history of family business in the Czech Republic has witnessed the first transfer of leadership of family businesses to the incoming generation. It seeks further trends in entrepreneurial activities, implements process management, and focuses on foreign markets. Compared to the founder generation, which in the Czech Republic began doing business following the year 1989 and opted for expansion primarily into Slovakia or Germany, it has no language barrier, it knows how to use sources of financing provided by the state for its export activities, it has the education and ambition necessary to succeed in global foreign markets.

This article is structured in the classical concept of a scientific study. The literature review presented serves as a literary input for examining the issues addressed, followed by the use of scientific methods and evaluation of findings. We close this document with a discussion, a summary of limitations, and proposals for future research.

\section{LITERATURE REVIEW}

Studies exploring export opportunities of SMEs are focused on the mutual causality of export and GDP. They reached the conclusion that growth in export is largely driven by export-ori- ented economies thanks to increased trade in specializing on industries with savings derived from scale, the application of research outputs, development, and accumulation of human capital (Bilan, 2009; Stancheva-Gigov \& Poposka, 2014; Kilic \& Beser, 2017). 
The research on family businesses and their ability to enter foreign markets has become a global topic. Initial research at the level of international business and family businesses was conducted by Gallo and Sveen (1991). They reached the conclusion that family businesses face numerous factors that either facilitate or limit their entry to foreign markets. They identified significant factors including company strategy, organizational structure, and phase of development in relation to intergenerational transfer. Other authors continue with this research. Kontinen and Ojala (2012) stated that family businesses traditionally operated on domestic markets but in order to survive in an increasingly competitive market were forced to become more international. As similar conclusion was reached by Pukall and Calabro (2014). Family businesses with access to intellectual capital and "intangible" sources of value in terms of a Resource-Based View (RBV) demonstrate greater intensity in their export activities than non-family businesses (Vallejo-Martos et al., 2016).

Yang et al. (2018) investigated the effect of family characteristics on the internationalization activities of Chinese family small and medium-sized enterprises (SMEs) using a socioemotional wealth perspective. They suggested that family ownership negatively affects international expansion. Results is that there is a negative relationship between family ownership and international activities. Authors were focus on both export intensity and export propensity, but also introduce family firm characteristics (i.e., presence of founder CEOs and family succession intention) as moderators. Authorsargue that these moderators capture a temporal aspect of socioemotional wealth and found that they strengthen the negative relationship between family ownership and internationalization (Yang et al., 2018). Applying the socioemotional wealth perspective of family businesses, authors examined how family control affects whether firms tend to go international. Result supports predictions that family involvement in management has an inverted-U-shaped relationship with the likelihood of internationalization and that the percentage of family ownership has a U-shaped relationship with the likelihood of internationalization (Liang et al., 2014)

The share in the economic growth of a country via entry of family businesses to foreign markets was the subject of study by Heck and Stafford (2001), Morck and Yeung (2003). Bilan (2009) analyzes diversification of export territory with a special focus on the legal and regulatory environment, education, technical preparation, and continuing education, policies to support business and economic integration for stimulating diversification of export. According to Bilan (2009), diversification is not the primary determinant of performance. Only a selected direction of diversification is a prerequisite for potential growth in performance. The choice of direction of diversification depends on the conclusions of analyses conducted, financial capital and human resources, as well as the overall preparedness of the company to service an international market. "Concentrating on one or two markets can be dangerous" (Bilan, 2009). A year later, Bilan and Yamko (2010) discussed the growing role of diversification of SME export activities under the conditions of globalization. They understand diversification of export as a complex phenomenon that is not only the focus of the exporter themselves, but is also influenced by the labor market, forms of government intervention, etc. They saw diversification of export as the main potential source of growth for SMEs.

The success of family businesses in relation to international trade was addressed by Arregle et al. (2017). Based on meta-analysis of 76 studies involving 41 countries, they reached the conclusion that success is determined by the role of controls and the age structure in company management, and dependency on the number of foreign territories served. Pukall and Calabro (2014) concluded on the basis of the Uppsala integration model that substantial success in realization of foreign trade by family business is driven by their knowledge and their capacity for building vendor-client networks and assessing the risks of a given project.

The international activities of family businesses, important for their competitiveness, are also addressed by Casillas and Moreno-Menéndez (2017). This study included analysis of 102 academic articles published from 1991 to 2015. The factor analysis they performed indicated the importance of proper definition of mission and goals for the selected territory or given field of business, company culture, position of management toward risks, timing, speed and tempo of entry to the selected 
territory, capacity for intercultural management, social capital, and outlook for building vendor-client relations.

The role of diversification of export territories can be a source of development potential for the SME segment according to Morkovina et al. (2018). In addition to diversification, the authors evaluated demand mechanisms for SMEs focused on export based on a comparative analysis of SME development in the countries of the EU and RF. They reached the conclusion that stimulation of export can be generated via tax and financial benefits, information service, consultation in the field of export operations, state bank guarantees, and insurance of export operations, stimulation of innovation during the creation of products for export, and education in foreign economic activities. Support of export companies, while it will have a positive result, is nonetheless limited by the size of the business, the demand for the products on offer, and the innovation potential of the family business.

The contemporary history of family businesses has been written since 1989. For the academic environment this topic has been a current issue primarily in recent years addressed by Odehnalová (2014), Hnilica and Machek (2015), Petlina and Koráb (2015), Petrů and Havlíček (2016), Machek (2017) and others. Rydvalová et al. (2016) consider family businesses to be a source of development of the entrepreneurial environment. Mareš and Petrů (2018) addressed factors of performance and stabilization of economies in the context of macroeconomic performance of SMEs using GDP. The export potential of SMEs in association with exchange rate was the subject of a study by Helísek (2013).

Economic theory typically considers growth driven by export as one of the growth strategies. The importance of the role of export for economic growth is discussed by Fitzová and Žídek (2015). Studies focus on the forms, processes, and methods of managing succession strategies, among other topics. Generation exchange is only one of many challenges that include digitization and robotization, pressure on technical development and innovation, globalization and significant integration of local, regional, and international markets (Servus, Elischer, \& Horáček, 2018).
The authors of the current study drew inspiration from a study by Moini, Kalouda, and Tesar (2008). This study focuses on factors influencing export of family businesses in the Czech Republic. The study generated the finding that exporting family businesses in the Czech Republic have a tendency to be more successful than their non-exporting counterparts, have more employees and large sales volume than non-exporting family businesses. Success in a foreign market is also ensured by product features such as uniqueness, price competitiveness, capability of the company to meet the needs and requirements of customers with their product, expertise of preparation of the entry of the company to the foreign market, creativity of the communications campaign, and sales support. Knowledge of significant international markets was highly rated. According to this study, family businesses in the Czech Republic identify their adjacent countries as the sole option for access to international markets.

Obstacles to business and positive attributes connected with family SMEs were the subject of a study by Břečková (2016). The author examined the export activities of SMEs, their typical features, and their contribution to overall export of the country, which reflected a slightly declining trend. On the contrary, with growing experience in foreign trade, a newly growing tendency was discovered for export outside the European Union. In this context it was argued that family businesses place emphasis on quality, innovation, value (Písař \& Havlíček, 2018), that family businesses present their own name, traditions, and know-how (Petrů, Havlíček, \& Tomášková, 2018), and as a result can be attractive to customers in foreign territories.

According to a survey by AMSP ČR carried out in May 2018 using CATI - computer-assisted telephone interviewing on a sample of 398 SMEs, the dominance of the EU as the most widely used export destination was confirmed, with Germany and immediately neighboring countries predominant. Outside the EU, exporters most frequently diversify their territorial risk by entry to the markets of the Commonwealth of Independent Nations, the Far East, other Asian countries, and North America (AMSP ČR, 2018).

It can be said that the ambiguity of the findings gathered lead to the realization that the results 
of domestic and international studies are hardly comparable. There is wide variation between the approach of researchers, research questions, hypotheses, forms of obtaining and evaluating information and size of study samples. They are influenced by economic and technical development of the examined territory, legislative and subsidy conditions in the country of the export activities, size of the company, demand for the products offered, the innovation potential of the family business and its ability to enter into a diversified market environment, pro-export activities and state support of business in international markets.

\section{OBJECTIVE, METHODOLOGY, AND DATA}

The primary goal of this article is to identify involvement of the generation of successors to export activities of family businesses, focusing on diversifying export territories in relation to structure of the industry. A secondary goal is to discuss the demand mechanisms for SMEs/family business oriented toward export. Two goals are set in this research. The reason for these two goals is their interconnection in the context of support for SME (family business), their relevance and practical applicability. This study was intended as the starting point for initiating long-term continual research whose purpose will be to map foreign expansion or success in foreign markets by family businesses managed by the second generation in the Czech Republic and to compare this with development in comparable economies. The findings achieved could be used for integrating academic and business spheres and could serve for discussion of the importance of state support of business in international markets.

\subsection{Hypotheses and research questions}

Diversification of export territories and the structure of the industry are important for the elimination of risks. One of the attributes of family businesses is the involvement of generations in management. The study hypotheses and research questions relate to the influence of generational in- volvement in company management, selection of export territories, and the structure of industries.

In order to fulfill the goals of this study, the following hypotheses and research questions were formulated:

H1: If the value of Pearson's correlation coefficient $r=0.600$, this indicates connection between export territories and the number of generations in the company management.

H2: If the value of Pearson's correlation coefficient $r=0.600$, this indicates connection of diversification between export territories.

H3: If the value of Pearson's correlation coefficient $r=0.600$ this indicates connection of the representation of generations in management. They export more companies where they are in management and 2 nd generation.

H4: If the value of Pearson's correlation coefficient $r=0.600$, this indicates connection between structure of industry and export territories.

RQ 1: Family businesses export to more than two territories.

RQ 2: Family businesses that manage 1st generation export more than 50\% to Slovakia and Germany.

RQ 3: Family businesses that manage only 2nd generation export more than $50 \%$ to outside the EU.

RQ 4: Automotive sector is predominantly structure of industry of exporting family businesses.

The correlation is the level of relationship. To evaluate the strength of the correlation, the guide that Evans (1996) suggests for the absolute value $r$ was used.

\subsection{Data sources and unique database description}

A unified definition of a family business that factors into applicable legislation does not yet exist. 
The Czech Statistics Office therefore has no obligation to gather data about this form of enterprise. Data about the real number of family businesses in the Czech Republic, which could be designated as the base set, are unknown.

Family business was defined for the purposes of this study in the following manner: family business includes business activities performed by spouses, other relatives of the first generation (parents, children, siblings), or other family members, provided that a minimum of $50 \%$ of shares in the company are owned by the members of a single family either on the basis of blood relation or other family ties, e.g. marriage. A family business may also be considered a form in which multiple generations of a single family work who are mutually connected by business policy and the objective of the owner is to transfer the company to the next generation. Here it must be noted that this is not a random sampling. Given the nature of the study problem (namely the unknown nature and size of the population that in general represents Czech family businesses), it was necessary to use data from the VŠFS database of family businesses. Secondary data obtained from publicly available sources was processed for identification of companies (the name of the company, address, legal form, year of incorporation, number of employees, field of business, export/non-export activities, export destinations, contact information, addresses, etc. were verified). Authors's definition is due to the fact that definition of "family business" is not yet legally anchored in the Czech Republic. However, the Czech government approved the definition of family business on May 13, 2019 (MPO, 2019). In accordance with Hlugha (2014) government itself indirectly impacts the economic growth by adopting new laws.

The source of the data is information from a unique database - the list of family businesses that has been created since 2015 at University of Finance and Administration (VŠFS). Data were obtained, for example, from the seminar papers of students the courses Modern Management and Business Model, it also contains data on companies that participated in the discussion roundtables organized by the Association of Small and MediumSized Enterprises and Tradesmen (AMSP). The data were also provided by the University of
Economics in Prague and the Technical University of Liberec. Both of these universities are part of the University Family Research Platform. VŠFS is the coordinator of research activities. The list is created by the method of "snowball" - the technique of qualitative research, is continuously supplemented, the processing is by the program Excel. The data are always checked in the administrative register of economic subjects.

The list includes the following information: company name; date of establishment and registration; family; company headquarters; scope of business, industry, sector; statistical legal form; number of employees; export aktivity; export territories; industry; generation; VAT; website, email address and phone of the owner and company; data box; notes, date of change.

Access rights to the database - head of Department of Business Management (the main administrator of the database), project solvers and AMSP. Currently (May, 2019) the database contains 3,621 family businesses.

For the purposes of hypotheses and highlights to research questions, the following data were used: export activity, export diversification (export territories), generation, industry.

The process for selecting the study sample was as follows:

1. A list of family businesses which has been generated by the VŠFS since 2015 contained data on 3,622 subjects as of the date the study was initiated.

2. Companies with the legal form of s.r.o. (limited liability company) and a.s. (joint-stock company) were selected $(N=2,416)$.

3. For the purposes of examining export, subjects were eliminated from the sample for whom no export activity has been reported $(N=1,499)$.

4. Subsequently, the following selection criteria were used for the purposes of this article: export - yes; the study sample contains 917 subjects. 


\subsection{Research methodology}

The method of analysis of secondary data, the method of quantitative research via questionnaire, and the method of qualitative research using personal semi-structured interviews were used for this study. The study sample $N=917$ was tested from a perspective of completeness of test variables using the program SPSS. The study sample met completeness of data at $100 \%$. The reliability of test data was then validated using Cronbach's Alpha. The Cronbach's Alpha value is 0.787; 0.689; 0.697 ; 0.812 , which indicates a good value of acceptability. Based on this value, the study data may be declared reliable.

3 variables were selected for this research:

- export destination - EU, outside the EU, Slovakia, Germany, global;

- generations: only 1st generation, 1 st and 2 nd generation, only 2 nd generation, 1st along with 2 nd and 3 rd generations;

- industries in which the company does business - automotive, food industry, mechanical engineering, glassworking, other.

The study operates from the presumption given by the study sample that the companies in question engage in export. The study focused on evaluating the relationship between export destinations, the number of generations in the management of the company, and the structure of the industries.

\subsubsection{Correlation analysis}

Correlations, in various forms, are the most common statistical characteristics throughout the technical literature (Řehák \& Brom, 2015). The purpose of the correlation analysis is to determine the mutual relationship of the given quantities. Dependencies between variables were determined using the method of calculating the Pearson's correlation coefficient, which measures the strength of the linear dependency between two quantities. It is then possible to define the strength of the link between the results of examined variables. The Pearson coefficient is a parametric statistical test that determines the tightness of the correlation between variables (up to 0.2 is a negligible correlation, 0.20 0.40 is a weak correlation, $0.40-0.70$ is a moderately tight correlation, $0.70-0.90$ is a very tight correlation, and more than 0.90 is an extremely tight correlation).

Pearson's correlation coefficient:

$$
r=\frac{\sum_{i=1}^{n}\left(x_{i}-\bar{x}\right)\left(y_{i}-\bar{y}\right)}{\sqrt{\sum_{i=1}^{n}\left(x_{i}-\bar{x}\right)^{2} \sum_{i=1}^{n}\left(y_{i}-\bar{y}\right)^{2}}},
$$

where $\bar{x}, \bar{y}$ are selection averages, $s_{x}$ and $s_{y}$ are selection standard deviations. The results of correlation analysis allow for hypotheses $\mathrm{H1}, \mathrm{H} 2, \mathrm{H3}$ and $\mathrm{H} 4$ to be validated or rejected. The correlation analysis will be explained in more detail with the research questions RQ 1, RQ 2, RQ 3, RQ 4. Correlation analysis was performed using the statistics program IBM SPSS ver. 25. The results of the correlation analysis are listed in Tables 2, 3, 4,6 . The correlation analysis is used to verify the connection between variables and is subsequently explained by the descriptive statistics method because of the uniqueness of the database being examined.

\subsubsection{Descriptive statistics}

Due to the uniqueness of the family business database (there are no statistical data on this subject in the Czech Republic) and the definition of family business by authors (family business is not yet legislatively anchored in the Czech Republic), descriptive statistics are used.

In statistical research, we are interested in mass phenomena and processes in which we examine patterns that manifest themselves in a large number of elements.

Monitored quantities:

- quantitative, described by numerical value (export destination, generation, industry);

- qualitative, described properties (export activities to the EU, outside the EU, Slovakia 
and Germany, worldwide; only 1st generation, 1 st and 2nd generation, 2nd generation only, 1 st and 2nd and 3rd generation; engineering, food, others).

Statistical tabulations and overviews were used to find answers to research questions (RQ 1-4). This form of descriptive statistics was chosen to select a unique dataset at the university. The data file meets the "export" condition, i.e. whether the company exports. In this case, it is an adequate and wellarranged method, which was processed by the statistical program IBM SPSS ver. 25 (Analyze Compare Means).

\section{EMPIRICAL RESULTS AND DISCUSSION}

The following text allows for hypotheses $H 1, H 2$, $H 3$, and $H 4$ to be validated or rejected and answers the research questions RQ 1, RQ 2, RQ 3 and RQ 4.
Table 1. Export/non-export activities of family companies - research sample

\begin{tabular}{|c|c|c|c|c|}
\hline Valid & Export & Frequency & $\begin{array}{c}\text { Valid } \\
\text { percent }\end{array}$ & $\begin{array}{c}\text { Cumulative } \\
\text { relative } \\
\text { frequency, } \\
\text { percent }\end{array}$ \\
\hline Valid & No & 1,499 & 62.0 & 62.5 \\
\hline Valid & Yes & 917 & 38.0 & 100 \\
\hline Total & Total & 2,416 & 100,0 & - \\
\hline
\end{tabular}

Table 1 presents export/non-export activities of family businesses. The result is result is that $38 \%$ export ( $\mathrm{N}$ 917) - this is research sample, there are companies included in database of family companies at the university).

H1: If the value of Pearson's correlation coefficient $r=0.600$, this indicates the connection between export diversification and the number of generations in the company management.

Table 2. Correlation analysis of variables: diversification of export and generations

\begin{tabular}{|c|c|c|c|}
\hline & & Diversification of export & Generations \\
\hline \multirow{3}{*}{ Diversification of export } & Pearson's correlation & 1 & $.798 * *$ \\
\hline & Sig. (2-tailed) & - & .000 \\
\hline & $\mathrm{N}$ & 917 & 917 \\
\hline \multirow{3}{*}{ Generations } & Pearson's correlation & $.798^{* *}$ & 1 \\
\hline & Sig. (2-tailed) & .000 & - \\
\hline & $\mathrm{N}$ & 917 & 917 \\
\hline
\end{tabular}

Note: ${ }^{* *}$ Correlation is significant at the 0.01 level (2-tailed).

Table 3. Correlation analysis of variables: diversification of export territories

Source: Author analysis, output from SPSS program.

\begin{tabular}{|c|c|c|c|c|c|}
\hline & & EU & Outside the EU & Slovakia, Germany & Global \\
\hline \multirow{3}{*}{ EU } & Pearson's correlation & 1 & $.523 * *$ & $.715^{* *}$ & $.599 * *$ \\
\hline & Sig. (2-tailed) & & .000 & .000 & .000 \\
\hline & $\mathrm{N}$ & 917 & 917 & 917 & 917 \\
\hline \multirow{3}{*}{ Outside the EU } & Pearson's correlation & $.523 * *$ & 1 & $.620 * *$ & $.788^{* *}$ \\
\hline & Sig. (2-tailed) & .000 & - & 0.000 & .000 \\
\hline & $\mathrm{N}$ & 917 & 917 & 917 & 917 \\
\hline \multirow{3}{*}{ Slovakia, Germany } & Pearson's correlation & $.715^{* *}$ & $.620 * *$ & 1 & $.552 * *$ \\
\hline & Sig. (2-tailed) & .000 & .000 & - & .000 \\
\hline & $N$ & 917 & 917 & 917 & 917 \\
\hline \multirow{3}{*}{ Global } & Pearson's correlation & $.599 * *$ & $.788^{* *}$ & $.552 * *$ & 1 \\
\hline & Sig. (2-tailed) & .000 & .000 & .000 & - \\
\hline & $\mathrm{N}$ & 917 & 917 & 917 & 917 \\
\hline
\end{tabular}

Note: ${ }^{* *}$ Correlation is significant at the 0.01 level (2-tailed). 
Table 1 shows correlation analysis of variables of diversification of export and generations. The value of the Pearson correlation coefficient is 0.798 , which indicates a strong positive dependence (0.60-0.79 strong value), which is confirmed by the value of Cronbach's Alpha of 0.787 . The hypothesis may be considered validated. The correlation analysis will be further supplemented by descriptive statistics, which will answer the research questions RQ 1, RQ 2, RQ 3.

This correlation analysis (Table 1) will be further analyzed by correlation of diversified territories for reasons of eliminating risks in global markets and by correlation of involving the 2nd generation of successors in the management of exporting companies that see in export an opportunity for company expansion and growth.

H2: If the value of the Pearson's correlation coefficient $r=0.550$, this indicates a moderate correlation of diversification between export territories.

Table 2 presents a correlation analysis of the variables of diversification of export territories. The values of the Pearson's correlation coefficient between the examined variables are in all cases higher than 0.500 (ranging from $r=0.523$ to 0.788 ) and the Cronbach's alpha value of 0.689 is also high, and therefore hypothesis $\mathrm{H} 2$ can be validated. The correlation analysis will be further supplemented by descriptive statistics, which will answer the research questions RQ 1, RQ 2, RQ 3.
The family companies examined export to multiple territories, as demonstrated by the examined variables. The highest level of correlation $(r=0.788)$ is between the variables of destinations outside the EU and global destinations, which indicates a growing tendency for companies to export to markets outside the EU and establish a global presence. If a company is successful in the EU market, its potential success in other high-priority global markets may be presumed (Brazil, PRC, India, Kazakhstan, Mexico, Russian Federation, Serbia, Turkey, Ukraine, USA, Vietnam, etc.).

The above strong positive level of correlation is a prerequisite for conducting separate correlation analyses of two variables - diversification of export and generations.

H3: If the value of the Pearson's correlation coefficient $r=0.600$, this indicates correlation between diversification representation of generations in management. Companies where the 2 nd generation is also involved in management are more engaged in export.

Table 3 presents a correlation analysis of the variables of generational involvement in exporting company management; the value of the Crohnbach's Alpha between these two variables is 0.697 , which is an acceptable value. The Pearson's correlation coefficient is in more than $2 / 3$ of cases higher than $r=0.550$. The highest correlation value $(r=0.722)$ in generational involvement in company management is for 1st generation only and

Table 4. Correlation analysis of variables: generational involvement in the management of exporting companies

\begin{tabular}{|c|c|c|c|c|c|}
\hline & & $\begin{array}{c}\text { 1st generation } \\
\text { only }\end{array}$ & $\begin{array}{l}\text { 1st and } 2 \text { nd } \\
\text { generations }\end{array}$ & $\begin{array}{c}\text { 2nd generation } \\
\text { only }\end{array}$ & $\begin{array}{l}\text { 1st, } 2 \text { nd, and 3rd } \\
\text { generations }\end{array}$ \\
\hline \multirow{3}{*}{ 1st generation only } & Pearson's correlation & 1 & $.722 * *$ & .421 & .401 \\
\hline & Sig. (2-tailed) & - & .000 & .000 & .000 \\
\hline & $\mathrm{N}$ & 917 & 917 & 917 & 917 \\
\hline \multirow{3}{*}{$\begin{array}{l}\text { 1st and } 2 \text { nd } \\
\text { generations }\end{array}$} & Pearson's correlation & $.722 * *$ & 1 & $.602 * *$ & $.599 * *$ \\
\hline & Sig. (2-tailed) & .000 & - & 0.000 & .000 \\
\hline & $\mathrm{N}$ & 917 & 917 & 917 & 917 \\
\hline \multirow{3}{*}{ 2nd generation only } & Pearson's correlation & .421 & $.602 * *$ & 1 & $.511 * *$ \\
\hline & Sig. (2-tailed) & .000 & .000 & - & .000 \\
\hline & $\mathrm{N}$ & 917 & 917 & 917 & 917 \\
\hline \multirow{3}{*}{$\begin{array}{l}\text { 1st, } 2 \text { nd, and 3rd } \\
\text { generations }\end{array}$} & Pearson's correlation & .401 & $.599 * *$ & $.511 * *$ & 1 \\
\hline & Sig. (2-tailed) & .000 & .000 & .000 & - \\
\hline & $\mathrm{N}$ & 917 & 917 & 917 & 917 \\
\hline
\end{tabular}

Note: $* *$ Correlation is significant at the 0.01 level (2-tailed). 
Table 5. Diversification of export territories and generational involvement in the management

Source: Author analysis, output from SPSS program.

\begin{tabular}{|c|c|c|c|c|c|}
\hline \multirow{2}{*}{ Generation } & \multicolumn{5}{|c|}{ Diversification of export territories } \\
\hline & EU & Outside the EU & Slovakia, Germany & Global & Total \\
\hline 1st generation only & 42 & 10 & 60 & 4 & 116 \\
\hline 1st and 2 nd generations & 20 & 308 & 12 & 108 & 448 \\
\hline 2nd generation only & 68 & 208 & 15 & 5 & 296 \\
\hline 1st, 2 nd, and 3rd generations & 5 & 35 & 2 & 15 & 57 \\
\hline Total & 135 & 561 & 89 & 132 & 917 \\
\hline
\end{tabular}

1st and 2nd generations; followed by 2nd generation only and 1st and 2nd generations $(r=0.602)$; then by 1st, 2nd, and 3rd generations and 1st and 2nd generations $(r=0.599)$, which indicates a continuous involvement of the 2 nd generation in the management of a company that sees in export an opportunity for company growth and expansion. Hypothesis $H 3$ may be considered validated. The correlation analysis will be further supplemented by descriptive statistics, which will answer the research questions RQ 1, RQ 2, RQ 3.

RQ 1: Family businesses export to more than two territories.

RQ 2: Family businesses that manage 1st generation export more than 50\% to Slovakia and Germany.

RQ 3: Family businesses that manage only 2nd generation export more than $50 \%$ to outside the EU.

Table 5 presents the answers using descriptive statistics (Analyze - Compare Means) on research questions RQ 1, RQ 2, RQ 3 and highlights the hypotheses $H 1, H 2, H 3$. The value of Pearson's correlation coefficient $r=0.600$ means the link between export diversification and the number of generations in management in the company. The investiga- ted family businesses export to more territories, as evidenced by the variables examined. RQ 1 can be answered in the affirmative. Variable 1st generation only confirms RQ 2: the companies that are managed by 1st generation export more than $50 \%$ to Slovakia and Germany (60 responses, 51.7\%). The 1st and 2nd generation variable is $416(308+108)$, $92 \%$ of companies confirm the diversification of foreign territories. The research question RQ 3 can be answered in the affirmative - companies with are managed by only 2 nd generation export more than $50 \%$ to outside the EU (208 responses, $70 \%$ ).

H4: If the value of Pearson's correlation coefficient $r=0.600$, this indicates connection between the structure of industry and diversification of export territories.

Table 6 presents the correlation analysis between the variables of diversification of export and the industry in which the company operates. It confirms a high level of correlation between the examined variables. The Pearson's correlation coefficient achieved a value of 0.801 , which is a value indicating a very strong positive correlation. The value of Cronbach's Alpha is also high at 0.812 ( $0.7 \leq a<0.9$ good, $0.91 \alpha \geq$ excellent). On the basis of these findings, hypothesis $H 4$ can be considered validated. This hypothesis $H 4$ will be highlights of RQ 4.

Table 6. Correlation analysis of variables: diversification of export territories and structure of industry

Source: Author analysis, output from SPSS program.

\begin{tabular}{|c|c|c|c|}
\hline & & Diversification of export & Structure of industry \\
\hline \multirow{3}{*}{ Diversification of export } & Pearson's correlation & 1 & $.801^{* *}$ \\
\hline & Sig. (2-tailed) & - & .000 \\
\hline & $\mathrm{N}$ & 917 & 917 \\
\hline \multirow{3}{*}{ Structure of industry } & Pearson's correlation & $.801 * *$ & 1 \\
\hline & Sig. (2-tailed) & .000 & - \\
\hline & $\mathrm{N}$ & 917 & 917 \\
\hline
\end{tabular}

Note: ${ }^{* *}$ Correlation is significant at the 0.01 level (2-tailed). 
Table 7. Diversification of export territories and structure of industry

Source: Author analysis, output from SPSS program.

\begin{tabular}{|c|c|c|c|c|c|}
\hline Industry & EU & Outside the EU & Slovakia, Germany & Global & Total \\
\hline Automotive & 99 & 301 & 80 & 58 & 538 \\
\hline Food industry & 10 & 6 & 2 & 14 & 32 \\
\hline Mechanical engineering & 13 & 189 & 7 & 49 & 258 \\
\hline Others & 13 & 65 & 0 & 11 & 89 \\
\hline Total & 135 & 561 & 89 & 132 & 917 \\
\hline
\end{tabular}

RQ 4: Automotive industry is predominantly structure of industry of exporting family businesses.

The industries in which more than $50 \%$ of the respondents contacted do business matches automotive industry, followed by mechanical engineering and food industry. Companies operating in these fields are represented globally.

\section{DISCUSSION}

First, it is appropriate to discuss the identified factors presented in the first phase of the study, then to address the outcome of the correlation analysis, discuss the arguments supporting the validation of the hypotheses, and to compare the outcomes of the above research with the outcomes of studies of selected authors cited in the literature review. Subsequently, to focus the discussion on demand mechanisms for SMEs oriented toward export.

It can be stated that family businesses, despite this term evoking for many the image of small firms of craftsmen, do not operate on a merely regional level, but are also successful exporters. Their export destinations are primarily the EU and the nearest neighbors of the Czech Republic, namely Germany and Slovakia, which confirms the long-term trend that small and medium-sized export-focused family businesses are dependent on the EU market. It must be noted that the EU countries continue to represent and will represent in future the most important audience for Czech exports. And yet the tendency is becoming ever more frequent to revert to the markets of the Commonwealth of Independent States, which witnessed a significant collapse in the last five years due to economic problems in Russia. These export destinations are serviced primarily by family businesses where the founding first generation of owners are involved in management. These destinations represent tradition and certainty to this founding generation. In the case of Slovakia, they have no need even to overcome a language barrier or logistical distance.

With the onset of the second generation, companies that have experience with export in the EU markets expand their export territories, establish a global presence (an example of such a company is LIKO-S, which offers its products in markets in India and USA, the company Beznoska, s.r.o., which has found success in the markets of Russia, Ukraine, Lebanon, Estonia, Mexico and more, the company EMCO, spol. s r.o., which has established a presence in USA and Russia and in another forty countries, Komfi, spol. s r.o. has found success in Japan, Thailand, and China). They thus become innovative exporters of their own products with high added value with considerable territorial coverage. The younger second generation has no language barrier, obtains education in universities and abroad, has no difficulties when searching for new business partners and subsequently managing individual business transactions with communicating via online communications tools. This finding matches those of Břečková (2016) and the outcomes of studies by AMSP ČR (2018). The fact, according to research by AMSP ČR and this study as well, that approx. a third of small and medium-sized companies export to eleven or more countries and that at least half export to six or more destinations would indicate that entrepreneurs of the second generation understand foreign trade as a natural opportunity for growing their sales, a tool for further development. This is also important information from the perspective of diversification of risks arising from dependence on the domestic market or several small countries. A similar finding was reached by Moini et al. (2010), while the importance of diversification was also highlighted by Bilan (2009) who considered it hazardous to export solely to one or two countries. 
It is necessary for the development of the economy for political representation and the broader public to properly understand the phenomenon of family business and its role in regions in particular. In regions they create jobs and generate profits that are invested in their development. At the same time, they spend this money, whereas a production cycle is created from which the given region benefits. This is something a global company cannot do.

The automotive industry, seconded by the food industry, represent significant commodities for export. Other industries worthy of note include the glass working and textile industries. The fact has been confirmed that the Czech Republic is an industrially oriented economy, and therefore dominated by intercompany trade, particularly in the manufacturing and mechanical engineering sector for the automotive industry. And yet this presents another topic for further discussion, of whether in the event of a crisis in engineering and the automotive industry as a whole, the diversification of export territories will protect existing exporters from risk of decreased sales and the stalling of their long-term development.

It can be stated that without good knowledge of local conditions, partners and customers, legal regulations, language, and also for example without market research, it will be difficult to succeed in foreign markets. Tools for success include a high-quality product, high-quality employees, long-term and open cooperation with business partners, and emphasis placed on innovation. At the same time, success is ensured in foreign markets for renowned family businesses by their history, traditions, know-how, reliability, long-term development objectives, and transfer to successor generations - in other words, by non-economic factors. This finding is compatible with the outcomes of the study by Vallejo-Martos et al. (2016).

A study of family business in the Czech Republic by Moini et al. in 2010 indicated that respondents do not consider state support to be adequate; if any such programs exist, respondents are unaware of them. The situation has significantly changed since 2010. According to the research outcomes of AMSP ČR (2018), companies have long confirmed a high level of knowledge of the activities of CzechTrade (97\%), 3 out of 10 companies have utilized its ser- vices to support export activities, 7 out of $10 \mathrm{com}$ panies are interested in utilizing such services; they also often resort to the Ministry of Industry and Trade and take advantage of the information for business owners in the area of international trade concentrated on the website BusinessInfo. $c z$. They seek out international partners in online databases of foreign RFPs, investment opportunities, international tenders, and products updated daily, and databases of foreign offers of services to Czech companies. The so-called Tým Česko (Team Czechia) has been carrying out the Export Strategy of the Czech Republic for the period from 2012 to 2020. It is based on three pillars:

1. Financial tools - export financing and insurance, international sources of financing and development partnerships - are provided by the Czech Export Bank, EGAP insurance company, Czech-Moravian Guarantee and Development Bank, and the Technology Agency of the Czech Republic.

2. Information and services - information for exporters, assistance and consultation services, services at the regional level, education for export - are provided by BusinessInfo, the Ministry of Industry and Trade, CzechTrade, CzechTourism, and the Technology Agency of the Czech Republic.

3. Development of business opportunities - expositions and trade shows, business policy, trade missions, bilateral economic relations, interior market, economic migration, investment for export - are provided by the Ministry of Industry and Trade, Ministry of Foreign Affairs, and the Technology Agency of the Czech Republic (MPO, 2018).

The primary goal of Tým Česko is to simplify access of companies to available state support, whether by sharing best practices, creating integrated product chains, or using synergies of shared products and services to support Czech businesses. Morkovina et al. (2018) in their comparative study reviewed all the above activities for SME support and development.

The conclusion can be made that even the changes made in direct export support lose their mean- 
ing if the state does not create a business environment based on low administration, support of innovations via support of study and research, implementation of trends associated with the "4th industrial revolution" (automation, digitization), creation of a favorable business climate, support of entrepreneurialism in foreign markets, support of family business, and efficiently targeted investments. It is necessary to mutually integrate the specific forms of support and not categorically separate them from each other. Even though the Czech Republic has been in first place now for two years in a row for support of foreign trade according to the Doing Business global rankings (World Bank), the opinion of entrepreneurs from numerous academic spheres cannot be understated, and the real needs of owners of family businesses must be heard. The state should not settle for positive perception of its services by businesses. The importance of removing barriers to trade on international markets was also positively expressed by Břečková (2016). Issues such as e.g. financial barriers, ethical and cultural differences, practices of the international market, localization of potential customers, diversification etc. are considered the greatest challenges for exporting family businesses in the Czech Republic. In order that state support mechanisms may be established for this group of businesses, however, family business must be established in legislation and regional in- fluences, economic parameters achieved, and their influence on the social environment must subsequently be monitored and compared with other business segments within the EU. To thereby create specific conditions on the bases of education, tax, investment, innovation, etc., to stimulate the founding, succession planning, and development of family businesses.

In its newly presented Innovation Strategy of the Czech Republic 2019-2030, the government of the Czech Republic declares that the support of science, research, and innovation, which is becoming a prerequisite for the success of SMEs in diversified international territories, is becoming more than just a mere phrase but in fact a concrete activity driven by the ambition to become a country of the technological future, ranked among the innovation leaders of Europe, within the next twelve years. "If we wish to retain our performance in a strong competitive environment, we have to focus on final production, technical solutions, and services based on knowledge. The objective cannot be merely to generate volume, but above all added value on domestic and foreign markets" (Office of the Government of the Czech Republic and Council for Research, Development, and Innovation, 2019). Support of exporting family businesses represents a unique opportunity to achieve this objective.

\section{CONCLUSION}

This article empirically contributes to research in the field of diversification of export territories of family businesses as a tool for their further development. Unlike developed economies, the contemporary history of family businesses in the Czech Republic has been written only since 1989. At present the first inter-generational exchange is taking place, and the task of the incoming generation is not only to sustain their family businesses, but also to develop them further. One of the forms is expansion to foreign markets, including diversification of the territorial risks associated therewith.

The primary goal of this article was to identify whether family businesses operate solely on a regional basis or whether they are diversifying their export territory with regard to their export activities. Subsequently to evaluate the diversification of export territories in relation to the involvement of the generation of successors in the management of the company, to demonstrate a correlation between the structure of the industry and export destinations, and to discuss the demand mechanisms for SMEs focused on export. It has been demonstrated that the family businesses examined operate not only regionally, but also export to multiple territories. This is traditionally to the market of the EU, which has constituted the most important export destination for some time, although they are also establishing a presence outside the EU in "priority" countries. This diversification of territories is the result of generational involvement in company management. Diversification is applied primarily in companies where 
the second generation of successors has been involved in management. A comparison of the correlation analyses of the variables of diversification of export compared to the number of generations managing companies demonstrates the fact that if a company is managed by the first generation of owners (entrepreneurs who in the majority of cases founded their companies after 1989), it predominantly services the market in Slovakia and Germany, in the EU countries. Companies being transferred or already transferred to successor generations are diversifying export territories outside the EU and establishing a global presence. As a successor to the family business EMCO spol. s r.o. says, ...I have no miracle recipe for establishing a presence abroad. It worked for us to differentiate from local producers, adapt our packaging, and especially have the right ratio of price to product quality, not fear initial failure, participate in international expositions and trade fairs through state agencies, and constantly seek and address potential customers.

A significant correlation was also demonstrated between the structure of industries and diversification of export. The industries in which more than $50 \%$ of the respondents contacted do business correspond to the automotive industry, followed by mechanical engineering and food industry. Companies operating in these fields are represented globally. It is indeed this export that advances these family businesses professionally. International partners have high demands for quality and innovativeness of products offered.

The study, whose limiting factor is the absence of a legislative foundation for family businesses and the variability of the startup business environment, should form a starting point for initiating a long-term study. Its purpose will be to continually map the development of family businesses managed by the second generation in the Czech Republic in comparison with development in comparable economies, to see options for their effective support and development in connection with the priorities of the individual economies. It will be important not only to describe and evaluate the conditions for international business activities of SMEs and the efficiency of state support, but also to analyze in greater detail the prerequisites for success of family businesses in selected countries within the EU and beyond (China, India, USA, Canada, Russia, etc.). To analyze whether Tým Česko is succeeding in creating a system of motivation for Czech family businesses investing abroad into innovative and technical projects. To understand the thinking of owners of family businesses, their options, needs, and expectations in relation to the execution of international business activities, as well as to capture the perspective of the technical public. To map out whether the expansion of family businesses to foreign markets contributes to regional development, GDP growth, and other economic indicators.

\section{ACKNOWLEDGEMENT}

The result was created in solving the student project No. 7427/2019/01 "Financial versus sociopsychological factors of family business" using objective oriented support for specific university research of the University of Finance and Administration.

\section{REFERENCES}

1. Abel, D. A., \& Seamus O’Brien. (2017). Family firms' management decision to export/not to export: A resource-based view. Journal of Advances in Management Research, 14(3), 270-287. http://dx.doi. org/10.1108/JAMR-06-2016-0053

2. AMSP ČR. (2018). 61. proband AMSP ČR: Trendy v exportu malých a středních firem. Retrieved from http://amsp.cz/ wp-content/uploads/2018/06/Ipsos-pro-AMSP_Export-Vysledkykom.-AMSPCT-opr.AMSP2_.pdf (accessed on June 12, 2018).

3. Andersen, O. (1993). On the internationalization process of firms: a critical analysis. Journal of Inter- national Business Studies, 24(2), 209-231. Retrieved from https:// link.springer.com/article/10.1057/ palgrave.jibs. 8490230

4. Arregle, J. L., Duran, P., Hitt, A., \& van Essen, M. (2017). Why is family firms' internationalization unique? A meta-analysis. Entrepreneurship Theory and 
Practice, 41(5), 801-831, https://doi. org/10.1111/etap.12246

5. Belás, J., Demjan, V., Habánik, J., Hudáková, M., \& Sipko, J. (2015). The business environment of small and medium-sized enterprises in selected regions of the Czech Republic and Slovakia. E+M Ekonomie a Management, 18(1), 95-110. Retrieved from http://publikace.k.utb.cz/ handle/10563/1004294

6. Bell, J., McNaughton, R., \& Young, S. (2001). Born-again global firms: an extension to the born global phenomenon. Journal of International Management, 7(3), 173-190. https://doi.org/10.1016/S10754253(01)00043-6

7. Benešová, D., Kubičková, V., Michálková, A., \& Krošláková, M. (2018). Innovation Activities of Gazelles in Business Services As a Factor of Sustainable Growth in the Slovak Republic. Entrepreneurship and Sustainability Issues: Peer-reviewed Scientific Journal. The General Jonas Žemaitis Military Academy of Lithuania, 5(3), 652-466. Retrieved from https://ideas.repec.org/a/ssi/ jouesi/v5y2018i3p452-466.html

8. Berlemann, M., \& Jahn, V. (2015). Regional Importance of Mittelstand Firms and Innovation Performance. Regional Studies, 50(11), 1819-1833. Retrieved from https:// www.tandfonline.com/doi/abs/10. 1080/00343404.2015.1058923

9. Bilan, Y. (2009). Increase diversification through strengthened enabling environment for Entrepreneurship: A focus on skill endowments and export orientation (example of Hungary and Poland) Economics and Sociology, 2(2), 3345. https://doi.org/10.14254/2071789X.2009/2-2/3

10. Bilan, Y., \& Yamko, P. (2010). Export diversification versus export orientation in the terms of globalization and complicated financial environment. Economics and Sociology, 3(1a), 11-26. Retrieved from https://www.economics-sociology. eu/?102,en_export-diversificationversus-export-orientation-in-theterms-of-globalization-and-complicated-financial-environment
11. Břečková, P. (2016). SMEs Export Activities in the Czech Republic and Export Risk Insuring. European Research Studies Journal, XIX(1), 84-92. Retrieved from https://ideas.repec.org/a/ers/ journl/vxixy2016ilp84-92.html

12. Casillas, J. C., \& Moreno-Menéndez, A. M. (2017). International business \& family business: Potential dialogue between disciplines. European Journal of Family Business, 7(1-2), 25-40. http://dx.doi. org/10.1016/j.ejfb.2017.08.001

13. Chong, S., Hoekstra, R., Lemmers, O., Van Beveren, I., Van Den Berg, M., Van Der Wal, R., \& Verbiest, P. (2019). The role of small- and medium-sized enterprises in the Dutch economy: an analysis using an extended supply and use table. Journal of Economic Structures, 8(1), 1-24. https://doi.org/10.1186/ s40008-019-0139-1

14. Delibasic, M. (2016). Hypothetical Matrix for Institutional Modeling of the Basis for Economic Development in the Countries of Southeast Europe. Montenegrin Journal of Economics, 12(2), 147-159. http://dx.doi.org/10.14254/18005845.2016/12-1/9

15. Draskovic, V., Popov, E. K., \& Peleckis, K. (2017). Modelling of Institutional Changes in Transition Countries - the Gap Between the Theory and Practice. Montenegrin Journal of Economics, 13(1), 125-140. Retrieved from https:// ideas.repec.org/a/mje/mjejnl/ v13y2017i1p125-140.html

16. Evans, J. D. (1996). Straightforward statistics for the behavioral sciences (600 p.). Pacific Grove: Brooks/Cole Pub. Co.

17. Fitzová, H., \& Žídek, L. (2015). Impact of Trade on Economic Growth in the Czech and Slovak Republics. Economics and Sociology, 8(2), 36-50. https://doi.org/10.14254/2071789X.2015/8-2/4

18. Gallo, M. A., \& Sveen, J. (1991) Internationalizing the family business: Facilitating and restraining factors. Family Business Review, 4(2), 181-190. https://doi.org/10.1111/j.17416248.1991.00181.x
19. Heck, R. K. Z., \& Stafford, K. (2001). The Vital Institution of Family Business: Economic Benefits Hidden in Plain Sight. In G. K. McCann \& N. Upton (Eds.), Destroying Myths and Creating Value in Family Business (pp. 9-17). Deland, Stetson University.

20. Helísek, M. (2013). Export Potential of SMEs and Euro Adoption in the Czech Republic. European Research Studies Journal, 16(4) 7178. Retrieved from https://www. ersj.eu/journal/404

21. Hlukha, H. Ya. (2014). Economic growth factors system: theoretical and methodological aspect (2014). Marketing and management of innovations, 1, 223-231.

22. Hnilica, J., \& Machek, O. (2015). Toward a measurable definition of family business: Surname matching and its application in the Czech Republic. International Advances in Economic Research, 21(1), 119-120. http:// dx.doi.org/10.1007/s11294-0149487-7

23. Kilic, N. \& Beser, M. (2017). Relationship of Foreign Trade and Economic Growth in Eurasian Economy: Panel Data Analysis. International Journal of Economics and Finance, 9(9), 1-7. https://doi. org/10.5539/ijef.v9n9p1

24. Kontinen, T., \& Ojala, A. (2012). Internationalization pathways among family-owned SMEs. International Marketing Review, 29(5), 496-518. https://doi. org/10.1108/02651331211260359

25. Krošláková, M., Kubíčková, V., Jurkovičová, L., \& Kubiniy, N. (2015). Dynamics of high growth enterprises - "gazelles" - in Czech Republic. Problems and Perspectives in Management, 13(2), 27-35. Retrieved from http:// businessperspectives.org/journals free/ppm/2015/PPM_2015_02_ Kroslakova.pdf

26. Kubičková, V., Krošláková, M., Michálková, A., \& Benešová, D. (2018). Gazelles in Services: what are the Specifics of Existence Slovakia? Management \& Marketing: The official journal of the Society for Business Excellence, 13(2), 929-945. https://doi. org/10.2478/mmcks-2018-0014 
27. Liang, X., Wang, L., \& Cui, Z . (2014). Chinese Private Firms and Internationalization: Effects of Family Involvement in Management and Family Ownership. Family Business Review, 27(2), 126-141. https://doi. org/10.1177/0894486513480885

28. Machek, O. (2017). Odměny zaměstnanců a jistota zaměstnání $\mathrm{v}$ rodinných podnicích: Důkazy $\mathrm{z}$ české republiky. Journal of East European Management Studies, 22(3), 362-373. http://dx.doi. org/10.5771/0949-6181-2017-3362

29. Mareš, D., \& Petrů, N. (2018). Stabilization factors of family enterprises in the context of macroeconomic performance. European Research Studies Journal, 21(1), 206-220. Retrieved from https:// ideas.repec.org/a/ers/journl/vxxy2017i3bp206-220.html

30. Means, B. (2016). Wealth inequality and family businesses. Emory Law Journal, 65(4), 937-986. Retrieved from https://papers.ssrn. com/sol3/papers.cfm?abstract_ $\mathrm{id}=2600042$

31. Meneses, R., Coutinho, R., \& Pinho, J. C. (2014). The impact of succession on family business internationalisation. Journal of Family Business Management, 4(1), 24-45. http://dx.doi.org/10.1108/ JFBM-01-2013-0004

32. Ministerstvo průmyslu a obchodu (MPO). (2019). Rodinné firmy se dočkaly, vláda schválila definici rodinného podnikání. Retrieved from https://www.mpo.cz/cz/rozcestnik/pro-media/tiskove-zpravy/ rodinne-firmy-se-dockaly--vladaschvalila-definici-rodinnehopodnikani--246105/ (accessed on May 22, 2019).

33. Ministerstvo průmyslu a obchodu MPO. (2018). Zpráva o plnèní Exportní strategie České republiky pro období 2012-2020. Exekutivní shrnutí za rok 2017. Retrieved from https://www.mpo.cz/assets/cz/zahranicni-obchod/podpora-exportu/ exportni-strategie/2018/4/zpravao-plneni-ES-2017.pdf (accessed on April 12, 2018).

34. Moini, H., Kalouda, F., \& Tesar, G. (2008). Foreign market entry: The case of SMEs in the Czech Republic. Journal of East - West Business, 14(1), 41-64. http://dx.doi. org/10.1300/J097v14n01_03

35. Morck, R., \& Yeung, B. (2003). Agency Problems in Large Family Groups. Entrepreneurship: Theory and Practice, 27(4), 367-382. https://doi.org/10.1111/1540-8520. t01-1-00015

36. Morkovina, S. S., Malitskaya, V. V., Panyavina, E. A., \& Sibiryatkina, I. V. (2018). Export Potential and Measures to Support Small and Medium-Sized Enterprises. European Research Studies Journal, XXI(1), 303-314. Retrieved from https://ideas.repec. org/a/ers/journl/vxxiy2018ispeciallp303-314.html

37. Neagu, C. (2016). The importance and role of small and mediumsized businesses. Theoretical and Applied Economics, 3(608), 331338. Retrieved from http://store. ectap.ro/articole/1217.pdf

38. Petlina, A., \& Koráb, V. (2015). Family business in the Czech Republic: Actual situation. Trendy Ekonomiky a Managementu, 9(23), 32-42.

39. Petrů, N., \& Havlíček, K. (2016). Specifics of the Development of Family Business in the Czech Republic. European Research Studies, 9(4), 88-108. Retrieved from https://www.um.edu.mt/library/ oar/handle/123456789/29579

40. Petrů, N., Havlíček, K., \& Tomášková, A. (2018). Comparison of marketing vitality of family and non-family companies doing business in the Czech Republic. Economics and Sociology, 11(2), 138-156. https://doi.org/10.14254/2071789X.2018/11-2/10

41. Písař, P., \& Havlíček, K. (2018). Advanced Controlling and Information Systems Methods as a Tool for Cohesion and Competitiveness of the European Union. In $V \check{S} B$ - Technical University of Ostrava. Proceedings of the 4 th International Conference on European Integration (pp. 1172-1181).

42. Prasetyo, H. A. (2016). What driver international competitive- ness? An empirical test in emerging Indonesian market. Journal of Competitiveness, 8(4), 124139. http://dx.doi.org/10.7441/ joc. 2016.04 .08

43. Pukall, T. J., \& Calabro, A. (2014). The internationalization of family firms: A critical review and integrative model. Family Business Review, 27(2), 103-125. https://doi. org/10.1177/0894486513491423

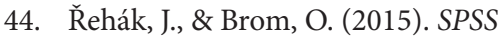
- Praktická analýza dat (336 p.). Prague: Computer Press.

45. Rydvalová, P., Horynová, E. K., \& Zbránková, M. (2016). Rodinný podnik jako zdroj rozvoje občanství v České republice. Amfiteatru Economic, 18(41), 168-183.

46. Sanders, W., \& Carpenter, A. (1998). Internationalization and firm governance: the roles of CEO compensation, top team composition, and board structure. Academy of Management Journal, 41(2), 158-178. https://doi. org/10.5465/257100

47. Servus, S., Elischer, D., \& Horáček, T. (2018). Aktuální otázky nástupnictví při rodinném podnikání (280 p.). Prague: Wolters Kluwer ČR. Retrieved from https://obchod.wolterskluwer.cz/ cz/aktualni-otazky-nastupnictvipri-rodinnem-podnikani.p4479. html

48. Stancheva-Gigov, I., \& Poposka, K. (2014). Foreign Trade and Economic Growth a Panel Regression Analysis. International Journal of Economics, Commerce and Management, 2(12), 1-10.

49. Sultan, S., de Waal, A., \& Goedegebuure, R. (2017). Analýza organizační výkonnosti rodinných a nečlenských podniků s využitím rámce HPO. Journal of Family Business Management, 7(3), 242-255.

50. Szymanska, K. (2015). The Importance of Family Businesses in The Economy. In Economical and Social Development, Book of Proceedings, Conference Istanbul (pp. 630-635). Varazdin: Varazdin Development and Entrepreneurship Agency (VADEA). Retrieved from https://www.esd-conference. 
com/past-conferences (accessed on April 30, 2019).

51. Tamas, C. (2018). Trade Relations and Trade Balances as The Indicators. In Economical and Social Development, Book of Proceedings, Conference Paris (pp. 301-313). Varazdin: Varazdin Development and Entrepreneurship Agency (VADEA). Retrieved from https:// www.esd-conference.com/pastconferences (accessed on April 30, 2019).

52. Tomášková, A., \& Havlíček, K. (2018). Family Enterprises and their Support through Subsidies. European Research Studies Journal, 21(2), 23-37. Retrieved from https://www.um.edu.mt/library/ oar/handle/123456789/33294

53. Úřad Vlády České republiky a RVVI. (2019). Rada vlády řešila plnění cílů Inovační strategie ČR a rozpočet na vědu na rok 2020. Retrieved from https:// www.vyzkum.cz/FrontAktualita. aspx?aktualita $=868988$ (accessed on March 30, 2019).

54. Vallejo-Martos, M., FuentesLombardo, G., \& Cano-Rubio, M. (2016). Intangibles in the internationalization of family firms: A source of competitive advantage. In Proceedings of the 8th European Conference on Intellectual Capital ECIC 2016, Ca' Foscari University of Venice, Italy (pp. 327-338). European Conference on Intellectual Capital. Kidmore End: Academic Conferences International Limited. Retrieved from https://books.google.cz/boo $\mathrm{ks} ? \mathrm{id}=8$ DOeDAAAQBAJ\&prints $\mathrm{ec}=$ frontcover $\& \mathrm{hl}=\mathrm{cs} \# \mathrm{v}=$ onepage $\& q \& f=$ false
55. Yang, X., Li, J., Stanley, L. J., Kellermanns, F. W., \& Li, X. (2018). How family firm characteristics affect internationalization of chinese family SMEs: APJM APJM. Asia Pacific Journal of Management, 36(113), 1-32. http://dx.doi.org/10.1007/ s10490-018-9579-7

56. Žižka, M. (2013). Multi-Dimensional Evaluation of Economic Pillar of Territorial Analytical Data. In R. Brol \& A. Sztando (Eds.), Local Economy in Theory and Practice: Planning and Evaluation Aspects. Research Papers of Wrockaw University of Economics (1st ed.) (No. 282, pp. 130-138). Wrocław: Publishing House of Wrocław University of Economics. 